\title{
TREE SPECIES SELECTION FOR STREET PLANTING IN THE CENTRAL BUSINESS DISTRICT OF RAJSHAHI
}

\author{
Md. Asaduzzaman' ${ }^{1}$, Nafis Sadat ${ }^{2}$ \\ ${ }^{1}$ Assistant Professor, Department of Architecture, Faculty of Civil \\ Engineering, Rajshahi University of Engineering \& Technology, Rajshahi- \\ 6204, Bangladesh \\ 2Undergraduate Student (4th Year), Department of Architecture, Faculty of \\ Civil Engineering, Rajshahi University of Engineering \& Technology, \\ Rajshahi-6204, Bangladesh \\ ${ }^{1}$ E-mail: asaduzzamansohag[at]gmail.com \\ 2E-mail: nafissadat123[at]gmail.com
}

\begin{abstract}
As flora is a significant part of the urban street system, careful consideration and attention should be given to tree species selection and plantation on an urban pedestrian walkway. This paper aims at analyzing the physical attributes of trees that grow naturally in Rajshahi and provides a basis for selecting suitable tree species for street planting in the Central Business District (CBD) of Rajshahi. Analytical method is used for selecting tree species by applying social factors of Miller's tree species selection model (1997) and street planting guidelines used in San Francisco, USA from an ergonomic and functional point of view as there is no proper regulation for street planting in Rajshahi. A questionnaire survey is also conducted in order to assess the public opinion regarding street trees from an aesthetic point of view. Future considerations for selecting tree species for street planting based on the findings can reduce problems at the neighborhood scale and thus increase the quality of urban life by enhancing the walking environment.
\end{abstract}

Keyword: Landscape Architecture, Street Planting, Attributes, Pedestrian, Walking Environment, Rajshahi. 


\section{INTRODUCTION}

Trees in urban areas are precious resources. Urban street trees are increasingly used as part of green infrastructure. Each tree has different physical and functional attributes. Hence careful species selection and planting is a must for utilizing the benefits provided by a particular tree. It is clear that urban trees enhance our quality of life and planting a single tree in an urban setting especially in the CBD area will yield a significant return on the investment. When people alter natural ecosystems and turn it into synthetic landscapes, they artificially select plant species based on a certain set of architectural requirements, without considering environmental requirements. Due to rapid urbanization, green infrastructure is decreasing at an alarming rate. It has negative impact on environment as well as social health of urban population. According to the Global Forest Watch, "Rajshahi has lost 12 ha of tree cover, equivalent to a $2.9 \%$ decrease in tree cover since 2000 , and 3.38kt of $\mathrm{CO}_{2}$ emissions. In 2010, Rajshahi had 105ha of tree cover, extending over $0.043 \%$ of its land area. In 2012, it lost $140 \mathrm{mha}$ of tree cover, equivalent to $36.4 \mathrm{t}$ of $\mathrm{CO}_{2}$ of emissions." [1] On the other hand, built area is increasing rapidly. In 1931-1940, total 393 buildings were constructed. This number dramatically increased to 32373 in the timeframe of 1991-2000. [2] This statistical information shows the rate of urbanization and rapid deforestation in the past few decades in Rajshahi. Being a divisional center, the CBD of Rajshahi is an economic and administrative nucleus. According to the Statistics and Informatics Division, Bangladesh Bureau of Statistics, total 4,49,756 people live in the city corporation area of Rajshahi, and almost $65 \%$ of this population along with numerous people from other cities have to come in the CBD area (ward no $09,10,11,12,13,20,21,22,23$ ) daily for an economic purpose. [3] The pedestrian walkways beside the primary roads in this area are very vibrant zones for economic purpose where street vendors sell their products. As a result of rapid urbanization, roadside trees are cut which leads to a discomfort walking environment in the summertime. To prevent further decrease in green infrastructure and enhance livability, tree plantation is the utmost effective solution especially in the CBD area. Urban street trees provide distinct edges to sidewalks which ensures secure walking environment. They also create vertical green barriers that help motorized vehicles guide their movement and assess their speed which results in overall speed reduction. Trees produce oxygen, intercept airborne particulates, and reduce smog, enhancing a community's respiratory health and reduces the body's stress level and alertness which allows it against pathogens, in case of COVID-19. "Business on tree-scaped streets show 12\% higher income streams as street planting enhances the walking environment." [4] Street trees enhance mental health and provide a joyous vibe. As a result, walking gives a pleasing experience. To fully maximize the potentiality offered by trees, careful consideration and attention should be given to the selection of tree species. This paper aims at finding out a set of selection criteria for choosing tree species for plantation on the sidewalks and road divider in the CBD of Rajshahi and recommend plant species based on those selection criteria. As there is no specific guideline for selecting tree species available in Bangladesh, ergonomic aspects of street planting guideline regulated by San Francisco Planning Department is taken into consideration. 


\section{LITERATURE REVIEW}

Though Bangladesh does not have any specific criteria for tree plantation on sidewalks, several universal sets of criteria can be found. These criteria work as a parameter for species selection for street planting in various aspects.

\subsection{TREE SPECIES SELECTION MODEL}

Robert W. Miller provided criteria for tree species selection for urban planting in 1997. He included four different aspects that have direct impact on species selection. These aspects determine whether a tree will grow and nourish on a specific site or not. According to this model, site factors, that include both environmental and cultural constraints, are the primary factors. "The physical limitations of the site which are caused by human, structural and activity are referred to as cultural constraints while insects, diseases, soils, climate and microclimate are referred to environmental constraints." [5] Site factors have direct impact on species selection as the growth and nourishment of the species depends on the climatic factors and the cultural acceptability of that species to the inhabitants on that particular site.

On the other hand, social factors refer to several aspects such as community values, neighborhood, functional utility, species aesthetics, public safety and negative social externalities. Economic factors include the establishment, management and removal costs. All these factors are important during the selection of trees species for street planting.

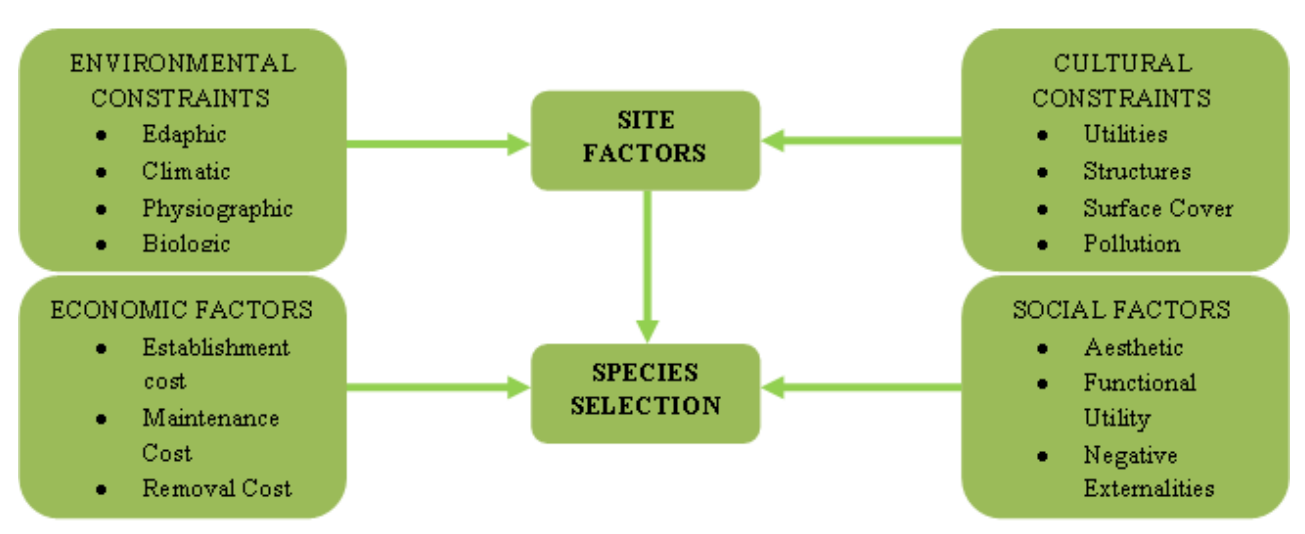

Figure 1: Species Selection Model by Miller (Drawn by Author)

\subsection{GUIDELINE FOR STREET PLANTING}

Bangladesh does not have any policy or regulation regarding functional aspects of street planting. As a result, random tree species are selected randomly for planting which fails to ensure the maximum potentiality offered by trees. In order to 
overcome this problem, street planting guideline followed in San Francisco is taken into consideration from ergonomic point of view. It also justifies the functional aspects of species selection model of Miller.

San Francisco Planning Department created and regulated a unified set of standards, guidelines, and implementation strategies for its streetscape elements that includes roads, street plantation and transportation. It creates an ergonomic correlation among trees on sidewalks, pedestrian and moving vehicles while enhancing aesthetic values. This guideline helps sort out the plant species that meet the functional parameters.

Table 1: Parameters for street planting

\section{Characteristics Preferred condition}

Clear height of branching from trunk

Maximum canopy size

Seasonal character

Leaf density

Distance between plants
Must not exceed the tree basin below $8 \mathrm{ft}$ height

Not exceeding $10 \mathrm{ft}$ at road dividers

Deciduous on Pedestrian and Evergreen on Median Road Divider

Moderate

Small trees ( $<20$ feet crown diameter at maturity) should be planted 15 feet on center Medium sized trees (20 to 35 feet crown diameter at maturity) should be planted 25 feet on center

Tall trees ( $>35$ feet crown diameter at maturity)

should be planted 35 feet on center"

"According to the guideline, street planting must be done wherever the existing pedestrian width is sufficient to accommodate plant growth and recommended throughway width. No trees should exceed its basin width below $8 \mathrm{ft}$ height for better circulation." [6] 


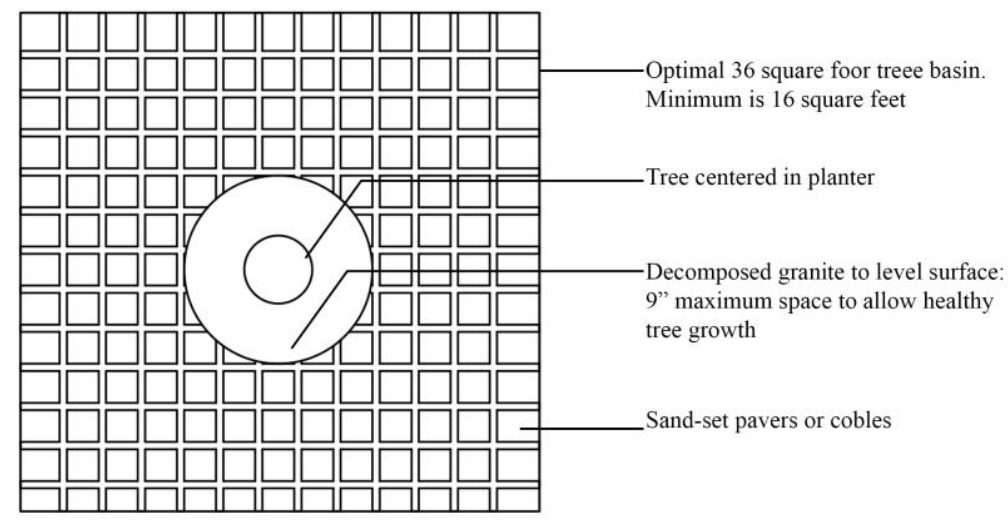

Figure 2: Tree Basin Detail (Drawn by Author) [6]

\section{RESEARCH AREA}

CBD area (ward no $09,10,11,12,13,20,21,22,23$ ) of Rajshahi City Corporation is considered as the study area as it is the most vibrant zone of Rajshahi City. All the roads in this area do not have defined sidewalks. Only the primary roads in this area have distinctive pedestrian walkways. This paper aims at finding out optimum species for street plantation on the sidewalks and road divider of these primary roads.

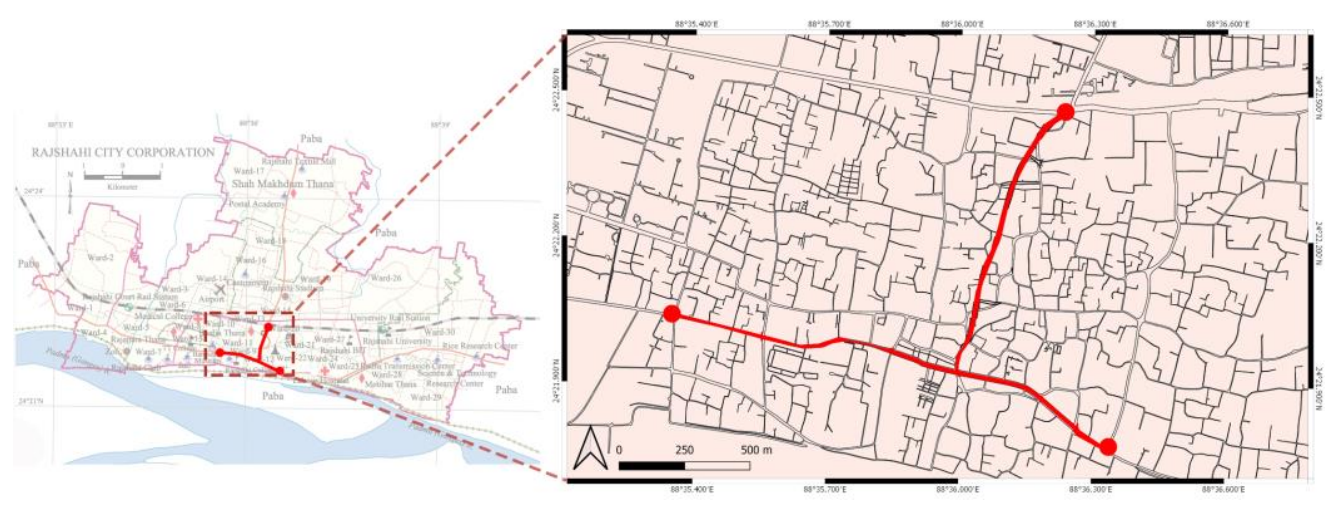

Figure 3: Research Area (Drawn by Author)

This is the economic nucleus of the district and prone to future expansion. The pedestrian pathways along the main arteries in this area are always very active as they serve both accessibility and as a business space for hawkers. But the existing condition of these pathways is not suitable for walking as they do not contain any 
shading trees and hence discourage walking especially during the summer season because of the hot and arid climatic condition. To overcome this problem, street planting is an eco-friendly solution that also enhances the walking environment and hence provides a basis for healthy living, working, shopping, sharing, walking and motoring in and through urban places in Rajshahi.

\section{RESEARCH METHODOLOGY}

Rajshahi is full of floral diversity. Selecting suitable species for street planting is a critical task as it has direct impact on urban livability. An annotated list of trees that grow naturally in Rajshahi region is collected from the 'Encyclopedia of Flora and Fauna of Bangladesh'; a multi-volume encyclopedia that has been published by Asiatic Society of Bangladesh. Physical attributes of these trees are analyzed and optimum species is selected for street planting by applying social factors of Miller's species selection model in case of street functionality and by comparing with the ergonomic aspects of planting guidelines applicable for street plantation in San Francisco. Tree satisfying these parameters can be considered for planting on the sidewalks and road divider on the primary roads of CBD in Rajshahi.

The below-mentioned flowchart shows the process of determining the optimum physical attributes of trees that enhances the walking environment at the street scale and selects suitable trees for planting accordingly

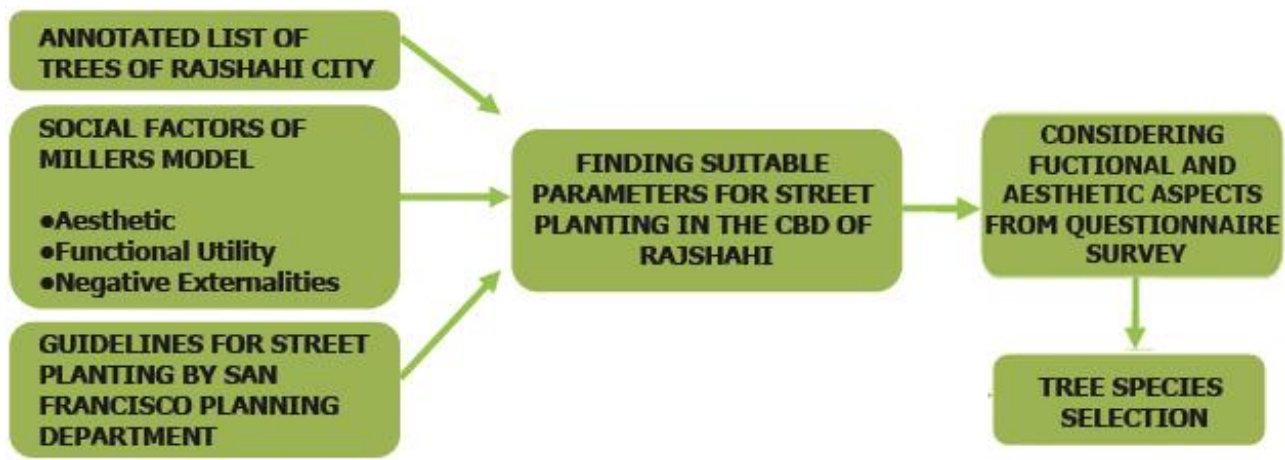

Figure 4: Species selection procedure (Drawn by Author)

Social Factors of Miller's model i.e. Aesthetic, Functional Utility and Negative Externalities rejuvenate the street environment by enhancing the walking and driving ambiance. Proper plantation of carefully selected trees provides shade on the pedestrian walkways in the summer without creating a visual barrier for the drivers. Rajshahi has a hot and dry climate with mild winter. The temperature varies from 10 to 36 degree Celsius. [7] As a result, the use of deciduous trees in pedestrian ways not only provides shade in summer but also allows sunlight to penetrate in winter that creates a comfortable walking environment. Again, an optimum clear height of branching from the trunk gives a clear view for both the drivers and people moving on foot and hence helps to circulate properly at the nodes and avoiding accidents. Moreover, trees having unsuitable odors may hamper the walking environment and large area of the root may hamper the built structures adjacent to the road. 


\section{RESULT AND DISCUSSION}

Some of the local trees that satisfies the functional and ergonomic guideline for street planting are divided into two basic groups-To be planted on sidewalks and to be planted on median road divider. A questionnaire survey was done among 50 pedestrians at the CBD area in order to measure the comfortability of the walking environment in this area. In this survey, they gave their opinion about their preferred walking environment on functional and aesthetic aspects.

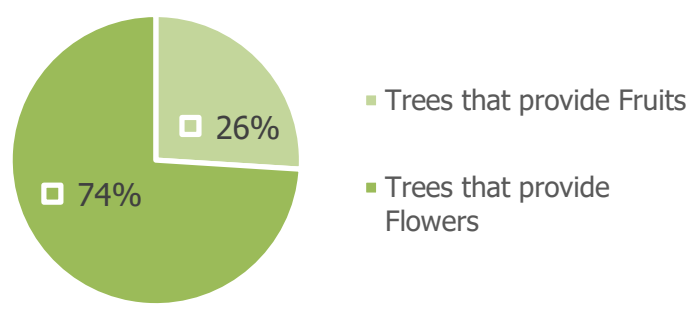

Figure 5: Public Opinion on preferable tree category for street planting (Drawn by Author)

The survey shows that $74 \%$ of the people prefer flowering plants on the sidewalks as the colorful view enhances their experience of walking. They gave their opinion about the preferred colors they want to see on the sidewalks and on the road divider.

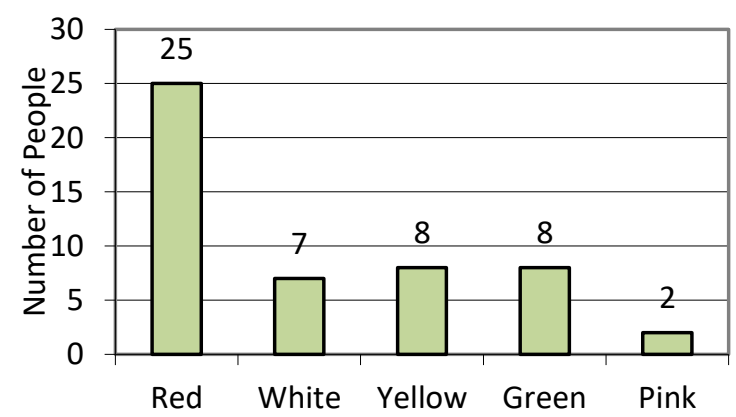

Figure 6: Public Opinion on preferable color of flowers for sidewalks. (Drawn by Author)

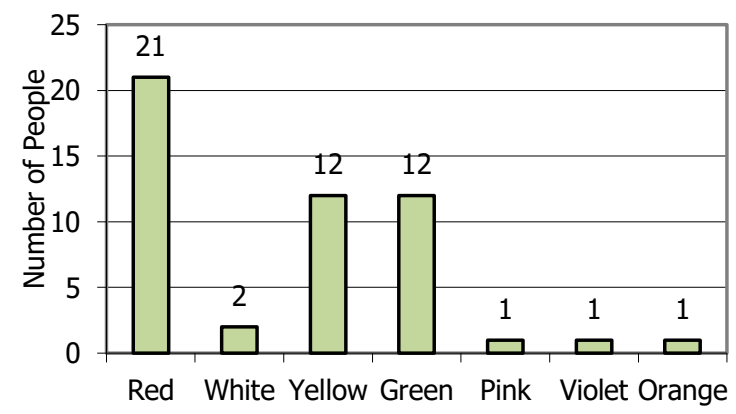

Figure 7: Public Opinion on preferable color of flowers for road dividers. (Drawn by Author) 
Figure 6 and figure 7 shows the colors preferred on the sidewalks and road divider by the pedestrian. It shows that red, yellow and green are the most preferred color among them. $100 \%$ of the pedestrians prefer nice fragrance on their walkways.

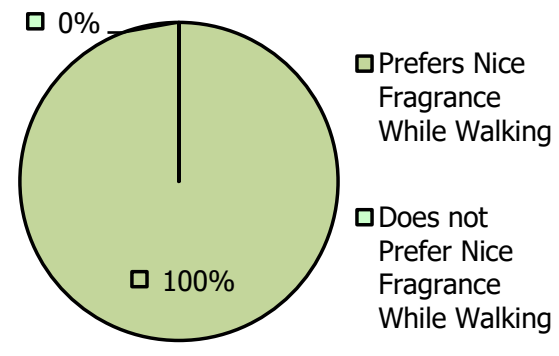

Figure 8: Public Opinion on fragrance from trees on pedestrian walkways. (Drawn by Author)

Most of them prefers shady trees on the sidewalks to provide shades during summer.

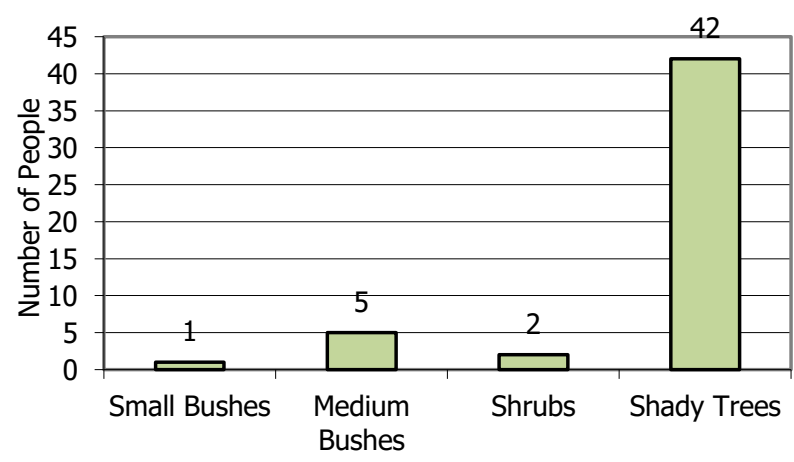

Figure 8: Public Opinion on tree selection for sidewalks. (Drawn by Author)

Among the 50 pedestrians, 20 people prefers medium bushes as they create a suitable visual barrier in order to omit glare from vehicles coming from the opposite side.

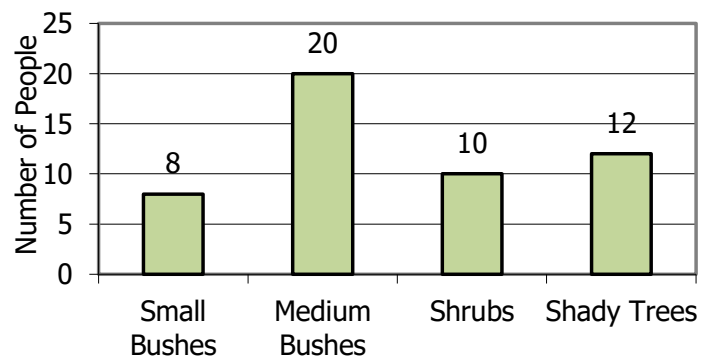

Figure 9: Public Opinion on tree selection for road dividers. (Drawn by Author) 
Considering the results of the questionnaire survey and the street planting guideline, trees are selected based on their physical attributes and functionality. Site factors such as climate, context, etc. are also considered while selecting tree species for street planting. These are not the only trees that fulfill the selection criteria; rather these can be a few examples for street planting. More species can be identified and may be selected for street planting based on the selection parameters.

Some of the trees that can be used on the roadside pedestrian area are as follows:

Table 2: Tree sample for planting on pedestrian area [8]-[17]

\begin{tabular}{|c|c|c|c|c|c|c|c|c|}
\hline $\begin{array}{l}\text { SI } \\
\text { no }\end{array}$ & $\begin{array}{l}\text { Local } \\
\text { Name }\end{array}$ & $\begin{array}{l}\text { Scientific } \\
\text { Name }\end{array}$ & $\begin{array}{l}\text { Max. } \\
\text { height } \\
\text { (ft) }\end{array}$ & $\begin{array}{l}\text { Max. } \\
\text { canopy } \\
\text { (ft) }\end{array}$ & $\begin{array}{l}\text { Trunk } \\
\text { size } \\
(\mathrm{cm})\end{array}$ & $\begin{array}{l}\text { Color } \\
\text { of } \\
\text { flower }\end{array}$ & $\begin{array}{l}\text { Seasonal } \\
\text { Category }\end{array}$ & $\begin{array}{l}\text { Leaf } \\
\text { Density }\end{array}$ \\
\hline
\end{tabular}

\begin{tabular}{|c|c|c|c|c|c|c|c|c|}
\hline 01 & Jarul & $\begin{array}{l}\text { lagerstroemia } \\
\text { speciosa }\end{array}$ & $45-65$ & $20-22$ & $\begin{array}{l}100- \\
150\end{array}$ & Violet & Deciduous & Moderate \\
\hline 02 & Neem & $\begin{array}{l}\text { Azadirachta } \\
\text { indica }\end{array}$ & $50-66$ & $\begin{array}{l}\text { Up to } \\
40\end{array}$ & $30-60$ & White & $\begin{array}{l}\text { Partly } \\
\text { Deciduous }\end{array}$ & Moderate \\
\hline 03 & Garjan & $\begin{array}{l}\text { Lannea } \\
\text { coromandelica }\end{array}$ & $40-45$ & $16-32$ & $\begin{array}{l}\text { Up to } \\
45\end{array}$ & Greenish & Deciduous & Moderate \\
\hline 04 & Krisnachura & Delonix regia & $30-40$ & $40-60$ & $\begin{array}{l}\text { Up to } \\
60\end{array}$ & Red & Deciduous & Moderate \\
\hline 05 & Babla & $\begin{array}{l}\text { Acacia } \\
\text { Senegal }\end{array}$ & $22-49$ & $16-26$ & $\begin{array}{l}\text { Up to } \\
30\end{array}$ & White & Deciduous & Moderate \\
\hline 06 & Pine & Araucaria sp. & $\begin{array}{l}\text { Up to } \\
100\end{array}$ & $10-20$ & $\begin{array}{l}\text { Up to } \\
25\end{array}$ & Reddish & $\begin{array}{l}\text { Partly } \\
\text { Deciduous }\end{array}$ & Moderate \\
\hline 07 & Segun & $\begin{array}{l}\text { Tectona } \\
\text { grandis }\end{array}$ & $30-78$ & $8-14$ & $\begin{array}{l}\text { Up to } \\
20\end{array}$ & White & Deciduous & Moderate \\
\hline 08 & Shonajhuri & $\begin{array}{l}\text { Acacia } \\
\text { auriculiformis }\end{array}$ & $40-80$ & $\begin{array}{l}\text { Up to } \\
40\end{array}$ & $\begin{array}{l}\text { Up to } \\
50\end{array}$ & Yellow & Deciduous & Moderate \\
\hline 09 & Chatim & $\begin{array}{l}\text { Alstonia } \\
\text { Scholaris }\end{array}$ & $\begin{array}{l}\text { Up to } \\
100\end{array}$ & $\begin{array}{l}\text { Up to } \\
32\end{array}$ & $\begin{array}{l}\text { Up to } \\
125\end{array}$ & White & $\begin{array}{l}\text { Partly } \\
\text { Deciduous }\end{array}$ & Moderate \\
\hline 10 & Jhau & Tamarix sp & $\begin{array}{l}\text { Up to } \\
60\end{array}$ & $10-20$ & $30-45$ & Reddish & $\begin{array}{l}\text { Partly } \\
\text { Deciduous }\end{array}$ & Moderate \\
\hline 11 & $\begin{array}{l}\text { Batabi } \\
\text { Lebu }\end{array}$ & $\begin{array}{l}\text { Citrus } \\
\text { maxima. }\end{array}$ & $16-50$ & $15-25$ & $10-30$ & White & $\begin{array}{l}\text { Partly } \\
\text { Deciduous }\end{array}$ & Moderate \\
\hline
\end{tabular}


\#5/2020 PLANNING

Some of the trees that can be used on median road divider area are as follows:

Table 3: Tree sample for planting on median road divider [18]-[23]

\begin{tabular}{|c|c|c|c|c|c|c|c|c|}
\hline $\begin{array}{l}\text { SI } \\
\text { no }\end{array}$ & $\begin{array}{l}\text { Local } \\
\text { Name }\end{array}$ & $\begin{array}{l}\text { Scientific } \\
\text { Name }\end{array}$ & $\begin{array}{l}\text { Max. } \\
\text { height } \\
\text { (ft) }\end{array}$ & $\begin{array}{l}\text { Max. } \\
\text { canopy } \\
\text { (ft) }\end{array}$ & $\begin{array}{l}\text { Trunk } \\
\text { size } \\
(\mathrm{cm})\end{array}$ & $\begin{array}{l}\text { Color of } \\
\text { flower }\end{array}$ & $\begin{array}{l}\text { Seasonal } \\
\text { Category }\end{array}$ & $\begin{array}{l}\text { Leaf } \\
\text { Density }\end{array}$ \\
\hline 01 & Debraru & $\begin{array}{l}\text { Polyalthia } \\
\text { longifolia }\end{array}$ & $40-66$ & $6-8$ & $25-30$ & $\begin{array}{l}\text { Greenish } \\
\text { Yellow }\end{array}$ & Evergreen & High \\
\hline 02 & Katamehedi & $\begin{array}{l}\text { Duranta } \\
\text { repens }\end{array}$ & $2-4$ & $1-2$ & $5-7$ & Violet & Evergreen & High \\
\hline 03 & Rangan & $\begin{array}{l}\text { Ixora } \\
\text { coccinea }\end{array}$ & $10-12$ & $3-5$ & $5-10$ & Red & Evergreen & Moderate \\
\hline 04 & Patabahar & $\begin{array}{l}\text { Codiaeum } \\
\text { variegatum }\end{array}$ & $3-8$ & $3-6$ & $14-18$ & White & Evergreen & Moderate \\
\hline 05 & Gada & $\begin{array}{l}\text { Tagetes } \\
\text { erecta }\end{array}$ & $0.67-3$ & $1-2$ & $\begin{array}{l}\text { Up to } \\
5\end{array}$ & $\begin{array}{l}\text { Yellow \& } \\
\text { Orange }\end{array}$ & Evergreen & Moderate \\
\hline 06 & Golap & Rosa sp. & $8-20$ & $1-15$ & $\begin{array}{l}\text { Up to } \\
15\end{array}$ & Red & Evergreen & Moderate \\
\hline 07 & Joba & $\begin{array}{l}\text { Hibiscus } \\
\text { rosa- } \\
\text { sinensis }\end{array}$ & $8-16$ & $5-10$ & $\begin{array}{l}\text { Up to } \\
15\end{array}$ & Red & Evergreen & Moderate \\
\hline
\end{tabular}

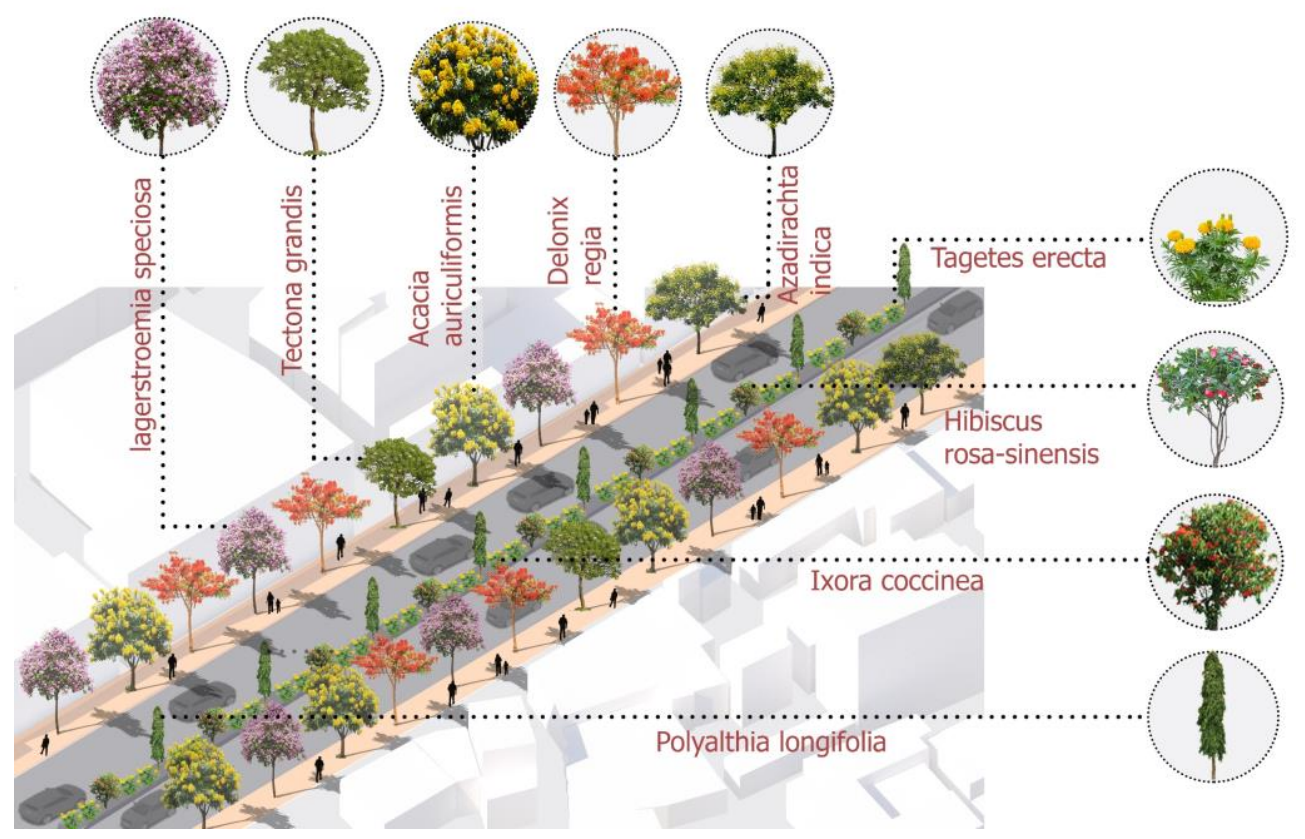

Figure 9: Axonometric View after street Planting. (Drawn by Author) 
Deciduous trees are selected for planting on the sidewalks so that they provide shade during summer and allows sunlight to enter in winter, thus ensuring the optimum comfortable walking environment. Evergreen small to medium bushes and shrubs are planted on the road dividers along with limited number of shady trees to ensure safe mobility.

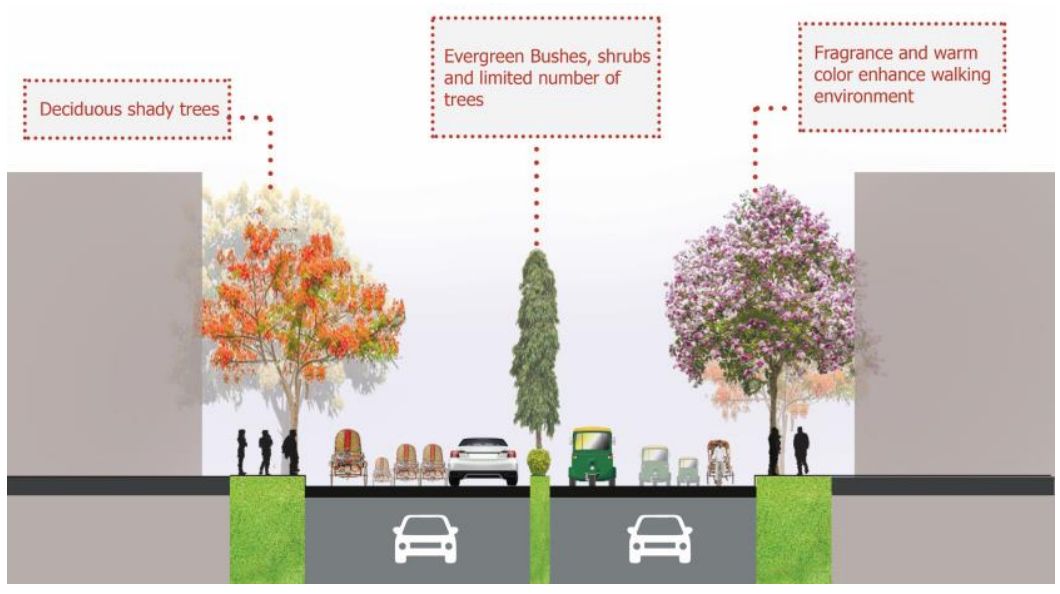

Figure 10: Street Section after Planting. (Drawn by Author)

\section{CONCLUSION}

Street trees are integral parts of the urban landscape as they enhance urban livability. Finding out what species to plant and where to plant is the key element of ensuring maximum potentiality offered by a particular tree. Hence species selection is a very critical factor as green spaces are critical for making cities sustainable, healthy and energy-efficient. To maximize this potentiality, tree plantation must be planned, designed, developed and maintained appropriately so that they are accessible both in terms of area and population coverage. "Views of vegetation and water (e.g. rivers or lakes) have been shown to reduce stress, improve healing, and reduce driving frustration and aggression. Views of green space from home are also linked to a greater sense of well-being and neighborhood satisfaction." [24] Trees are living elements of our street infrastructure. Located on the public right-of-way, they provide cooling shade, cleaner air, and more beautiful urban streetscapes and provide ecological benefits to city residents also. In the case of the CBD area of Rajshahi, street planting will be a smart solution towards healthy and sustainable living and working. Deciduous shading trees can provide shade in hot and humid summer and allow sunlight to penetrate during winter. Again, Evergreen decorative trees will provide an optimum barrier between streets if they are used on road dividers. Hence, careful plant selection can solve the walking and driving problems existing in urban streets in the CBD of Rajshahi. 


\section{REFERENCE}

[1] "Rajshahi Deforestation Rates \& Statistics | GFW." [Online]. Available: https://rb.gy/rmgoes. [Accessed: 28-Jul-2020].

[2] F. J. Sarmin and M. S. U. Zaman, "GIS-based extraction of open Space in Rajshahi city," 1st Int. Conf. Comput. Inf. Eng. ICCIE 2015, pp. 162-165, 2016, doi: 10.1109/CCIE.2015.7399304.

[3] Bangladesh Bureau of Statistics, "District Statistics 2011 Rajshahi District Statistics 2011," no. December, 2013.

[4] D. Burden, "Urban Street Trees: 22 Benefits," pp. 1-21, 2006.

[5] J. P. Miller, Robert W.; Hauer, Richard J.; Werner, Urban Forestry: Planning and Managing Urban Greenspaces. .

[6] A. Varat, Better Streets: Streetscape Elements. 2008, pp. 171-233.

[7] "Rajshahi, Bangladesh - Detailed climate information and monthly weather forecast | Weather Atlas." [Online]. Available: https://www.weatheratlas.com/en/bangladesh/rajshahi-climate. [Accessed: 04-Sep-2020].

[8] E. F. Gilman and D. G. Watson, "Lagerstroemia speciosa: Queens Crapemyrtle 1," no. January 1998, pp. 1-3, 2014.

[9] NABARD, "Neem- A Versatile Tree. Model Bankable Projects," 2011.

[10] T. Satheesan, S. Sivachandiran, and T. Sivananthawerl, "Height and Diameter Relationship of Tectona grandis L . in Mullaitivu District of Sri Lanka Height and Diameter Relationship of Tectona grandis L . in Mullaitivu District of Sri Lanka," no. June, 2017.

[11] W. D. Brush, "Teak (Tectona grandis).," vol. Foreign Wo, p. 12 p, 1937.

[12] D. Sawant, Trupti P.; Panhekar, "A BRIEF REVIEW ON RECENT ADVANCES OF CITRUS MAXIMA (CHAKOTA)," Int. J. Recent Sci. Res., vol. 10, no. 5, pp. 32535-39, 2019, doi: 10.24327/IJRSR.

[13] B. Pratap, G. S. Chakraborthy, and N. Mogha, "Complete aspects of alstonia scholaris," Int. J. PharmTech Res., vol. 5, no. 1, pp. 17-26, 2013.

[14] B. E. Jackson, R. D. Wright, and J. O. James, "Pine Tree Substrate: Current Status Pine Tree Substrate: Current Status," 2015, no. February.

[15] J. Schmerbeck and N. Naudiyal, "Acacia auriculiformis," Enzyklopädie der Holzgewächse Handb. und Atlas der Dendrol., no. January 2014, pp. 1-12, 2015, doi: 10.1002/9783527678518.ehg2014002.

[16] "Acacia arabica ( Gum-Arabic tree ) Size / Shape Acacia arabica ( GumArabic tree )."

[17] R. Poinciana, E. F. Gilman, and D. G. Watson, "Delonix regia," no. November, pp. 1-3, 1993.

[18] S. Verma, "International Journal of Research in Hibiscus rosa-sinensis L . ( Malvaceae ): A Multipurpose Ornamental Plant," vol. 6, no. 1, pp. 61-64, 2017.

[19] OGTR, "The Biology and Ecology of Rosa x hybrida ( Rose )," Aust. Gov., no. December, p. 18 p., 2005, doi: 10.1002/14651858.CD000990.pub3.

[20] G. Gopi, A. Elumalai, and P. Jayasri, "A Concise Review on Tagetes Erecta," Int. J. Phytopharm. Res., vol. 3, no. 1, pp. 16-19, 2012.

[21] N. O. M. Commun, "Codiaeum variegatum.," no. October, pp. 1-3, 1999.

[22] M. S. Baliga and P. J. Kurian, "Ixora coccinea Linn.: Traditional uses, phytochemistry and pharmacology," Chin. J. Integr. Med., vol. 18, no. 1, pp. 72-79, 2012, doi: 10.1007/s11655-011-0881-3. 
[23] A. V Puri, "Duranta Repens Linn. (Verbenaceae): a Comprehensive Review of Pharmacognostic, Ethnomedicinal, Pharmacological, and Phytochemical Aspects," Asian J. Pharm. Clin. Res., vol. 11, no. 11, p. 91, 2018, doi: 10.22159/ajpcr.2018.v11i11.28509.

[24] Lynne M. Westphal, "Urban Greening and Social Benefits: a Study of Empowerment Outcomes," J. Arboric., vol. 3, no. 29, pp. 137-147, 2003.

Article distributed under a Creative Commons AttributionNonCommercial-NoDerivatives 4.0 International License (CC BY-NC-ND). Received: July 23, 2020 Accepted: October 26, 2020 